\title{
Efficacy of Selected Aqueous Plant Extracts, Fungicides and their Combinations against Disease and Pest Control on Tomato in Hamelmalo
}

\author{
Niat Yemane, Russom Kiflu, G. Yonatan Teklemariam, \\ G. Sethumadhava Rao* and Y. Syed Danish \\ Department of Plant Protection, Hamelmalo Agricultural College, Keren, Eritrea \\ *Corresponding author
}

\begin{abstract}
A B S T R A C T
\end{abstract}
The tomato (var. sumberson) is highly susceptible to diseases caused by microorganisms as well as pest infestations; as a result serious loss is caused thereof in the production of those crops. On the background of these facts, the research was focused on controlling the diseases through the selected treatments with the objectives of evaluating the efficacy of Lantana camara extract, Balanites extract and their combinations to assess on controlling the pest/disease incidence and severity in tomato field conducted in Hamelmalo Agricultural College. The experiment was conducted in RCBD with the treatments: Lantana flowerextract, foliar fungicide (Mancozeb), soil fungicide (Sulphur dust), and Balanites seed kernel extract, combinations of fungicides with Lantana extract and Balanites extract and Control. The insect pests i.e. Leafminer, Whitefly and African boll worms; two bacterial diseases: Bacterial rot and Bacterial speck; one fungus: Early blight and a viral disease were recorded in the field during the study period. Aqueous extract of Balanites seed kernel and Mancozeb, after treatment, also showed good control on both early blight and soft rots. There was a significant difference among all the treatments in every disease recorded in comparison to control. In the case of disease severity, the treatments of $\mathrm{T} 1, \mathrm{~T} 2$ and $\mathrm{T} 4$ showed drastic decrease in the early blight whereas T6, T5 and T1 showed drastic reduction in soft rots on tomato. A drastic control of Leafminer was noticed by T2 and T6 from $18.4 \%$ to $7.5 \%$ and from $19.3 \%$ to $11.3 \%$ before and after treatments, respectively.

\section{Introduction}

Tomato (Lycopersicon esculentum Mill) belongs to Solanaceae and is the second most important vegetable crop next to potato. The estimated world production of tomato is about 89.8 million $\mathrm{mt}$ from an area of about $3,170,000 \mathrm{ha}$; the leading producers are China (with $25.3 \%$ of the total production), USA, Mexico and Egypt (Basheer, 2006). This nightshade family member is an important component in the diets of majority of Eritreans and alsoit serves as a cash crop for many farmers (Figure 1). High yields of tomato result in high incomes to farmers especially in areas such as Anseba, Gashbarka, and Asmara when it is cultivated on large scale particularly in the dry season. In Eritrea, the areas of high tomato production concentrations are in Hamelmalo, Keren, Elabred, Hagaz and ZobaMaekel. The tomato fruit has been found to have considerable health benefits (Asgedom 
et al., 2011). In Eritrea, tomato is grown mostly under irrigation, and sometimes under rain fed conditions. Due its phenology, less investment and high demand in the market, farmers encouraged to grow tomato. Yet, the average yield of tomato in Eritrea has remained low, $15 \mathrm{Mt} \mathrm{ha}^{-1}$, compared with $19 \mathrm{Mt} \mathrm{ha}^{-1}$ on average in Africa, $23 \mathrm{Mt} \mathrm{ha}^{-1}$ on average in Asia and $27 \mathrm{Mt} \mathrm{ha}^{-1}$ on average worldwide (MoA, 2000). In most parts of Eritrea production of tomato is possible only twice a year like Mai-ayni (June - September in the highland) and Forto-Sawa (April - July in the lowland). Local farmers differentiated the tomato based on varietal characteristics as San marzano (angular) and as Mar globe (round). For a number of scientific reasons San marzano varieties are more preferable to Mar globe varieties (Asgedom et al., 2011). Besides some institutional constraints, the farmers have also been facing, incidence and severity of diseases, pest infestations, and physiological disorders.

\section{Diseases and Pests on Tomato in Eritrea and Other East African Nations}

These diseases could cause yield losses of up to 10 to $15 \%$ (Agrios, 2005). Eritrean farmers indicated that insects like whiteflies and African boll worm (ABW) account for only $5 \%$ of the total yield loss. American ball worm was perceived to be the most serious insect pest among many tomato producers. Insects like leaf miner, leaf hopper and aphids also cause some damages but are considered to be less problematic (Asgedom et al., 2011).

In East Africa the major insect pests of tomato include: leaf miners, white flies (those transmitting the tomato yellow leaf curl virus), tomato bugs, thrips (Tomato Spotted Wilt Virus), fruit worms, and spider mites. The major diseases of tomato prevalent in East African countries include: bacterial canker, speck, and spot, bacterial wilt, fusarium wilt, early blight, late blight, powdery mildew, root-knot-nematodes, viral diseases (tomato spotted wilt virus, tomato mosaic virus, tomato yellow leaf curl virus), blossom-end rot (Sithanantham, 2004). One of the investigations of Sethumadhava et al., 2016 reveals that the most common diseases are infected by fungal, bacterial and viral that are transmitted by pests are found in all surveyed villages i.e. Wazntet, Awrari, Genfelom, Basheriand Hamelmalo in subzoba Hamelmalo. Early blight and late blight were the most common in all villages while the diseases caused by pests such as tomato borer and Septoria leaf spot rarely found. Powdery mildews were observed in both Wazntet and Genfelom villages.

Farmers use chemicals such as Afghan, Bylaton, Euparen and Daconil with the advice of the extension agents of the Ministry of Agriculture. However, the most farmers do not have a thorough understanding of disease types and their control measures. Though the synthetic, broad-spectrum fungicides and insecticides are a satisfactory solution for fungal and pest control; but the indiscriminate use of chemical applications is a threat to natural ecosystem, environment and human health. Plant extracts such as species of the neem tree, sweet flag, onion, garlic, custard apple, pyretrum, derris, common Lantana, holy basil, black pepper, and common ginger have been used for several centuries and were known in tribal or traditional cultures around the world (Weinzierl, 1998). These botanicals keep attracting and more attention given worldwide as they are considered as a suitable alternative to synthetic insecticides. Besides designation of currently inadequate botanical treatments which are efficient and somehow more effective as well as less expensive is bringing the Eritrean local farmers the challenges of facing low management practices in their tomato fields. Hence this research is being proposed to meet the 
objectives to calculate the disease incidence, severity and yield loss due to diseases; the percentage of pest infestation; evaluate the efficacy of extracts of Lantana camera and Balanites aegyptica as botanicals, pesticides and their combinations on control of diseases of tomato.

\section{Major Insect Pests Recorded in Tomato Crop}

The specific miner of tomato crop is called as Loriomyza trifoli which attacks usually on tomato leaf tissues and often on fruits and can cause tremendous economic losses in suitable conditions for immediate attack and multiplication (Byers, 2015). They are leafminers, whitefly [Trialeurodes vaporariorum(Hemiptera)] (Flint, 2006), African boll worms (Helicoverpa armigera) are major pests of 25 wild host plants plus some major crops including tomato (Cherry et al., 2003). All these pests can cause 14-16 percentage economic losses that may, however, vary in different seasonal periods and in particular geographical locations of Eritrea. These pests are playing interesting roles in disease development on a particular environmental condition by serving up a variety of disease causal agents the essential epidemiological needs and factorize their quantity of inoculum per an infection locus. Such insect pests are called vectors of diseases.

\section{Materials and Methods}

\section{Experiment Site}

The experiment was conducted in the fields of Hamelmalo Agricultural College (HAC) from the late winter season until early summer. Hamelmalo is located $13 \mathrm{~km}$ North of Kerenand the altitude of the area is about 1330 $\mathrm{m}$ above mean sea level (Fig. 2). The average rainfall and annual temperature of the area are $436 \mathrm{~mm}$ and $24^{\circ} \mathrm{C}$ respectively.

\section{Experimental Design}

The experiment was conducted in a randomized complete block design with two controls in the treatments (the untreated control and the standard control) in which the treatments are Lantana camara flower extract, fungicides (Mancozeb and sulphur Dust), combinations ('Lantana flower extract 5\% and Sulphur dust', 'Sulphur dust and Mancozeb', 'Balanites seed kernel extract 5\% and Mancozeb') and control. Response of the tomato variety to Lantana flower extract, Balanites seed kernel extract, fungicides, and their combinations of these treatment levels was studied. Each treatment was replicated three times in a total of 24 experimental plots. Each experimental plot consists of 4 rows of 5 tomato planted with a spacing of $30 \mathrm{~cm}$ between each tomato plant in a row and with spacing of $75 \mathrm{~cm}$ between the rows. The data was collected from the 3 randomly selected and tagged plants from each of the 24 plots. The tomato seedlings were watered at regular intervals of 5-7days until the emergence of flowers thereafter were watered at 3-4 regular intervals and will be stopped until few green fruits are remained on the field (Fig. 3).

\section{Preparation of aqueous extract of Lantana camara flowers}

The fresh plant material of Lantana camara Linn. (Family: Verbenaceae) was collected from the farm areas of HAC and carried in reusable plastic bag and was placed in a freezer to maintain its turgidity. The fresh flowers were detached from the tested plant materials and are subjected to fine powdered form. Hundred grams from the powdered flower samples was weighed and mixed in $1000 \mathrm{ml}$ distilled water. The solution was boiled, cooled until room temperature and filtered through the cheese cloth followed by filtration by Whatman No.1 filter paper. Then the filtrate was kept under normal room 
temperature and was sprayed on tomato plants on15-day interval for two months (Eweis and Amber, 2011).

\section{Preparation of aqueous extract of Balanites aegyptiaca seed kernels}

Five kilogram of dried seeds of Balanites aegyptiaca (Family: Zygophyllaceae) were collected from the surrounding of HAC. The seeds were smashed down and all the pulp ground by using pistil and grinder to a fine powder from which 500 grams were weighed, taken in different containers and mixed in $100 \mathrm{ml}$ distilled water to collect $5 \%$ extraction percentage of concentration. For about 24 hours the filtrate in the flask was allowed to remain in the laboratory at room temperature. At last stage of extraction the liquid filtrate in the two flasks was brought in one and kept under normal temperature and was sprayed on the tomato crop on 15-day interval for two months (Bishnu and Zeev, 2005) (Fig. 4).

\section{Formulation and Application of Chemicals}

Available fungicides (Mancozeb, Pungix, and sulphur dust) were formulated and applied at recommended dosage on the tomato crop.

Application of the plant extracts was in foliage area and was carried out until the end of this study with 7-days intervals. Foliar sprays were, generally, applied twice (7-day interval) using knap sack sprayer (Table 1).

\section{Data Collection}

Detailed assessment on incidence and severity of important diseases and pests infestations percentage on tomato in accordance to the primary objectives of the research was carried out on 72 randomly selected plants out of 24 plots in the HAC field. The observations were recorded on 7 days post-spray and 1 day prespray basis with regard to the most prevalent (fungal, bacterial, and viral) diseases and pests (insects) of tomato.

\section{Observation for pest infestations}

The pre-treatment observation were recorded at 1-day before spraying while the post treatment observations were recorded on the $1^{\text {st }}$ day after each three spray at 7 days interval.

\section{Leaf miner}

Three plants per plot were selected at random and six leaves (two at upper, two at middle and two at lower) in every plant were observed for the phyto-extract and to calculate the percentage infestation by leaf miner, 18 leaves of three selected plants, were observed.

$$
\left[\% \text { Leaf infestation by leaf miner }=\frac{\text { No. of damage leaf observed }}{\text { Total No. of leaf observed }} \times 100\right]
$$

\section{White fly}

Three plants per plot were selected at random and the numbers of nymph and adult flies were counted in each plant.

\section{Fruit borer}

According to Rishikesh, 2013, the following data were assessed.

Larval population: The trial was observed on three randomly selected plants per plot. The number of larva as per fruit was physically recorded at pre-treatment and 7 days after treatment.

Percentage of damaged fruits: After each picking, the numbers of damaged and healthy fruits were recorded to calculate the damage percentage. 
Percentage losses of fruit yield: Fruits of all the pickings were separated in to healthy and infested fruits to calculate the percentage weight losses.

$\left[\%\right.$ losses of fruit yield $\left.=\frac{\text { Damaged fruits }(w t .)}{\text { Total fruits }(w t .)} \times 100\right]$

\section{Observation for Diseases Incidence and Severity}

Disease Incidence (DI) was assessed by the following formula:

$$
\text { Percentage of diseaseincidence }=\frac{\text { No. of infected plants }}{\text { Total no. of plants }} \times 100
$$

Disease Severity (DS) with the preformed disease index were recorded and calculated as following formula:

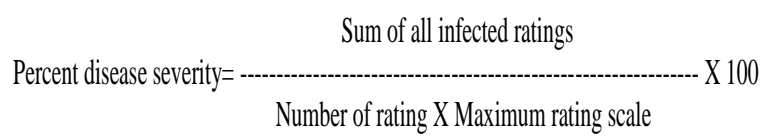

The disease severity was calculated by using 0-9 scale of Reifshneider et al., (1984). Where Grade-0 means no conspicuous symptoms are observed and Grade-9 indicates all leaves and stems drying and dead due to disease (Table 2).

\section{Data Analysis}

All the data collected were subjected for statistical analysis of variance by using GENSTAT software package at 5\% level of significance.

\section{Results and Discussion}

Among the observed diseases and infestations by pests, three were insect pests i.e. Leaf miner, White fly and Fruit borer; two were bacterial diseases i.e. Bacterial rot and
Bacterial speck; one fungus i.e. Early blight and a viral disease caused by Tomato Leaf Curl Virus were recorded (Table 3 ).

The major insect pest, Leaf miner (Loriomyza trifoli) was noticed during the third week after plantation. The damage is caused by the apodous maggot which makes whitish zigzag infestation between epidermal layers of leaf which could be seen by holding the leaf against bright-light. White flies (Bemisia tabaci) were appeared on the fourth to fifth week after plantation and were observed sucking the cell sap from the lower surface of the leaves and transmit the leaf curl viruses which later become prevalent on the plant. Larvae of Fruit borer (Helicoverpa armigera) pest were observed feeding on tomato fruits by making holes. The pest infestation appeared after two months of plantation when the fruits were first seen. Bacterial speck disease caused by Pseudomonas syringae was recorded after first and during second month after plantation. The specks are very small and do not penetrate the fruits deeply and is first seen in the green fruits. Bacterial rot caused by Ralstonia solanacearum was observed wherever the insect pest infestations are recorded. Symptoms of Tomato Leaf Curl Virus which are transmitted by a whitefly appeared during the second month after plantation, the symptoms were upward curl of the leaves, dropping of flowers and stunting the plant. Early blight symptoms due to Alternaria solani were observed at the end of the first month; they were developed as dark concentric rings and encircled by yellow colour margins on the leaf surface (Fig. 5).

The results of efficacy of various treatments (T1 $=$ aqueous extract of Lantana flowers (LE); T2= aqueous extract of Balanites seed kernel (BSKE); T3= Fungicide for Soil borne fungus (SBF) $\mathrm{T} 4=$ Fungicide Foliar Spray (FSF); T5= T1+T3; T6= T3+T4; $77=\mathrm{T} 2+\mathrm{T} 4$; $\mathrm{T} 8=$ Control) on 'percentage of disease 
incidence' is given in table 4. The overall maximum disease incidence was observed in early blight at T8 (Control) $85.58 \%$ and the lowest disease incidence is observed in bacterial rot, caused by Ralstonia solanacearum, of T6 ('Sulphur dust and Mancozeb') which is $5.56 \%$. In overall, after treatment, the increasing trend in disease incidence of early blight (Alternaria solani) was noticed in T8.The highest decreasing phenomenon of Tomato Leaf Curl Virus (TLCV) is observed in T2 (Aqueous extract of Balanites seed kernel 5\%) from $72.22 \%$ to $68.67 \%$ which is so accounted for $3.55 \%$ decrease. The maximum disease incidence of bacterial speck is observed in T4 and very low is recorded in T6 as well as T3.

Maximum increase in bacterial rot incidence is seen in T8 and maximum decrease is recorded in T5. The T7, T5 and T3 showed relatively effective control over all diseases. T6 and T1 showed high effect on almost all diseases after treatment. It is supporting to the research done by Eweis et al., 2011 that the antimycotic behavior of essential oil of flower of Lantana camara was effective on mycelial growth, conidia and/or sclerotia germination and had a significant inhibitory effect on the sclerotia/conidia in development and germination.

Effect of various treatments on 'percentage of disease severity' is presented in table 5. Early blight severity showed a maximum increase from $14.55 \%$ to $23.75 \%$ in T5 and from $7.78 \%$ to $11.3 \%$ in $\mathrm{T} 8$ and the highest reduction from $16.33 \%$ to $11.3 \%$ was observed in $\mathrm{T} 2$ (Aqueous extract of Balanites seed kernel 5\%) among all other treatments. Hence it is conforming to the research done by Chapagain et al., (2007) who reported that saponin rich extracts (4\%) from Balanites aegyptiaca fruit mesocarp, showed $34.7 \%$ growth inhibition against $A$. solani. The current results obtained were in supporting that, Balanites seed kernel extract also had antimicrobial activity against selected strains of Gram-positive bacteria, Gram-negative bacteria, and Candida (Ashaal et al., 2010). The increased disease severity of bacterial rot from $3.55 \%$ to $5 \%$ was noted in $\mathrm{T} 8$ and maximum decrease was observed in T6 from $4.27 \%$ to $1.78 \%$. The highest progress of disease severity was observed in early blight by T5 (before treatment $14.55 \%$ to after treatment $23.75 \%$ ). T6 showed a significant difference when applied against bacterial speck and maximum decrease of bacterial speck severity was shown by $\mathrm{T} 1$ from $14.27 \%$ to $12.2 \%$ which is so accounted for $2.07 \%$ decrease. The highest disease severity among all other diseases was recorded in leaf curl viral disease of T8 $(26.61 \%)$ and maximum decrease of leaf curl severity was noticed by $\mathrm{T} 2$ before treatment $14.83 \%$ and after treatment $12.22 \%$.

In general, the maximum severity was observed in TLCV of T8 (26.61\%) after treatment, and the lowest severity was seen in bacterial speck of T8 (1.11\%) before treatment. There was a significant difference among all the treatments in every disease recorded in comparison to control. The C.V. that occurred in bacterial rot was recorded to be 25.6 and the reason for this could be due to the highest variant pest infestation of Helicoverpa armigera associated particularly with the bacterium causing the rot infection.

Table 6 shows the effect of various treatments on 'percentage of pest incidence'. The population per plant of African Boll Worm (ABW) showed a maximum $(25 \%)$ in $\mathrm{T} 7$ after treatment and it was controlled both in $\mathrm{T} 2$ and T6 from $21.15 \%$ to $13.34 \%$ and from $11.53 \%$ to $8.33 \%$ respectively. However a drastic control of $\mathrm{ABW}$ was noticed by $\mathrm{T} 1$ and $\mathrm{T} 2$ from $7.69 \%$ to $1.67 \%$ and from $21.15 \%$ to $13.34 \%$ before and after treatments respectively. 
Fig.1 Average Area of Cultivation and Average Yield in Five Regions of Eritrea

\section{Cultivation and Yield of Tomato in five Zobas}

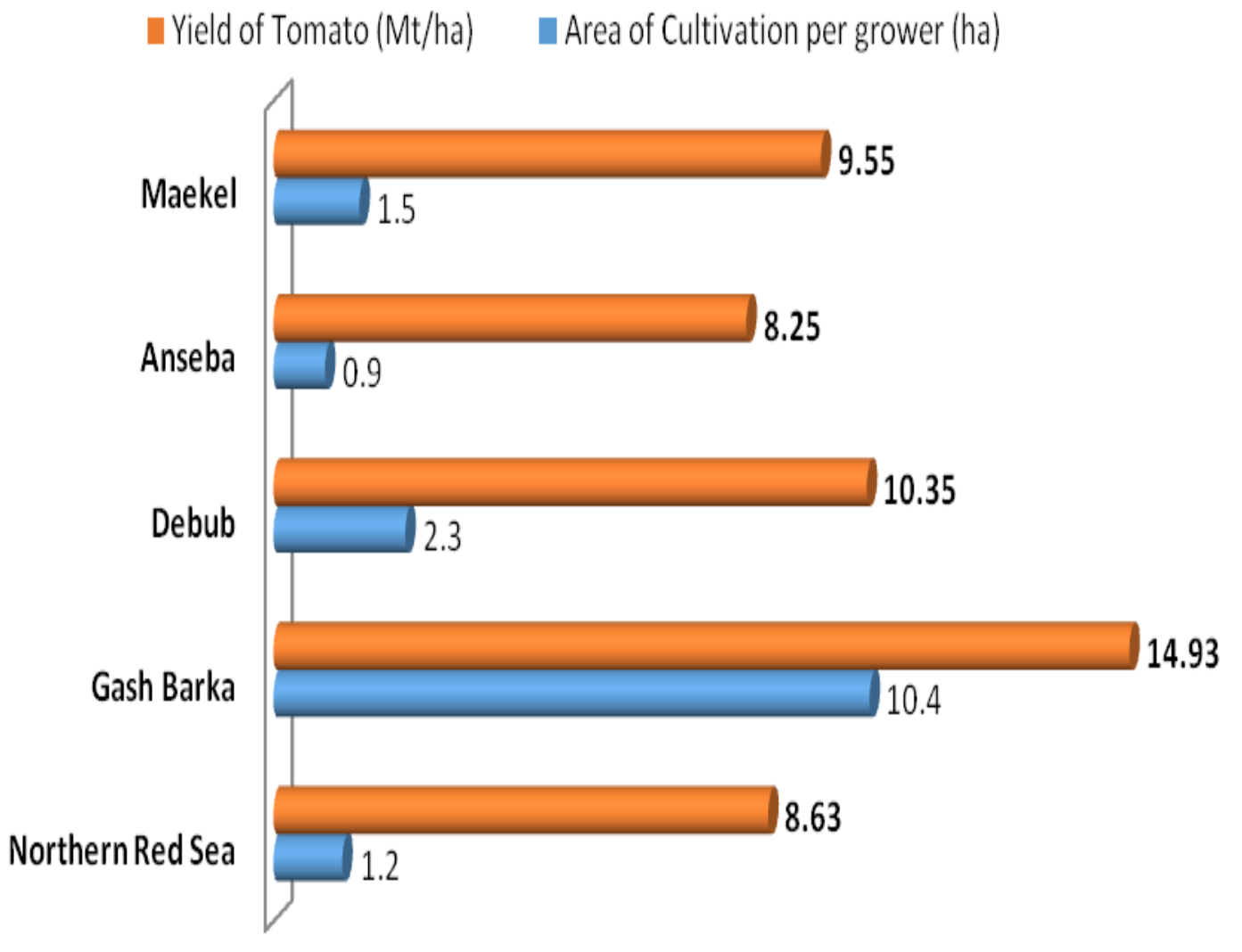

(Source: Asgedom et al., 2011)

Fig.2 The Experiment Site in the Campus of HAC in ZobaAnseba (4), Eritrea

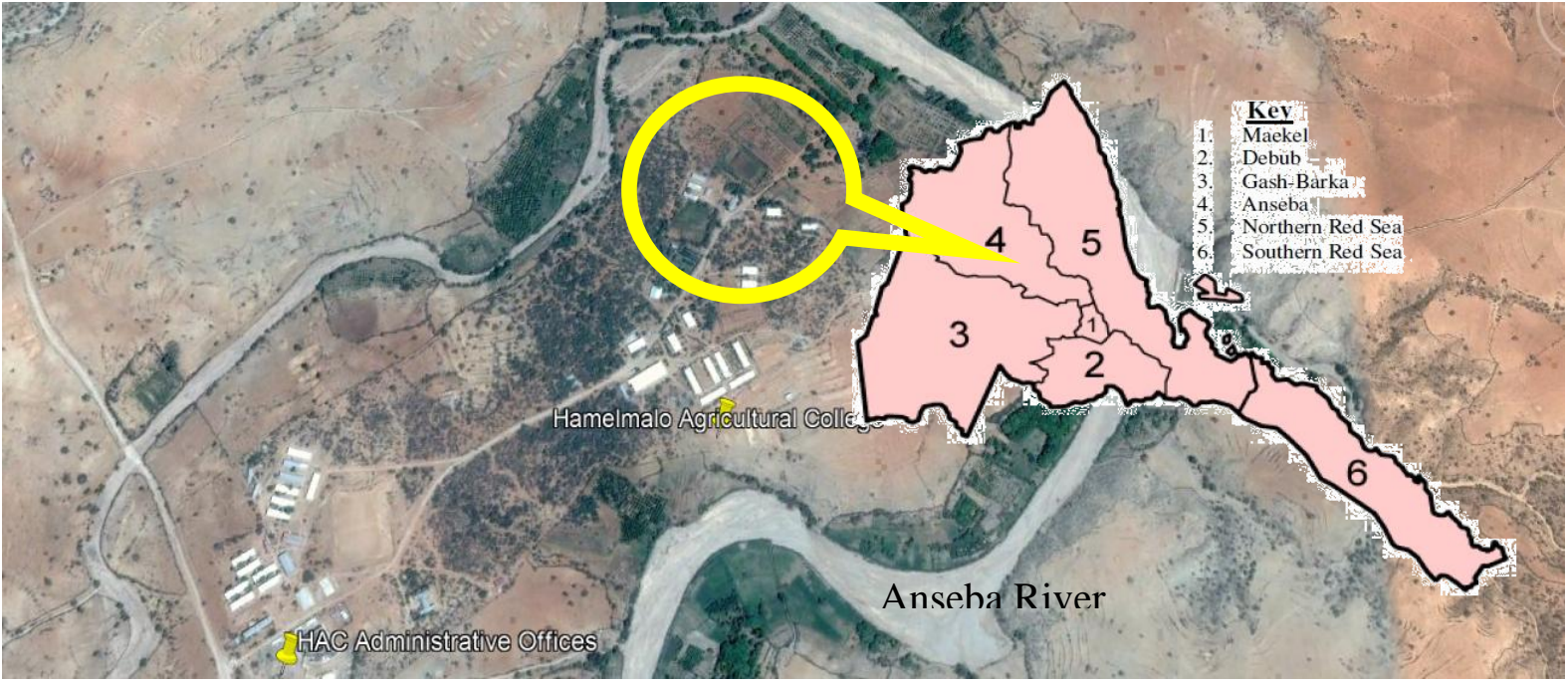


Fig.3 Seedlings (A) are ready to Transplant; Field Preparation (B) for the Cultivation of Tomato; Weeding (C) and Data Collection (D)

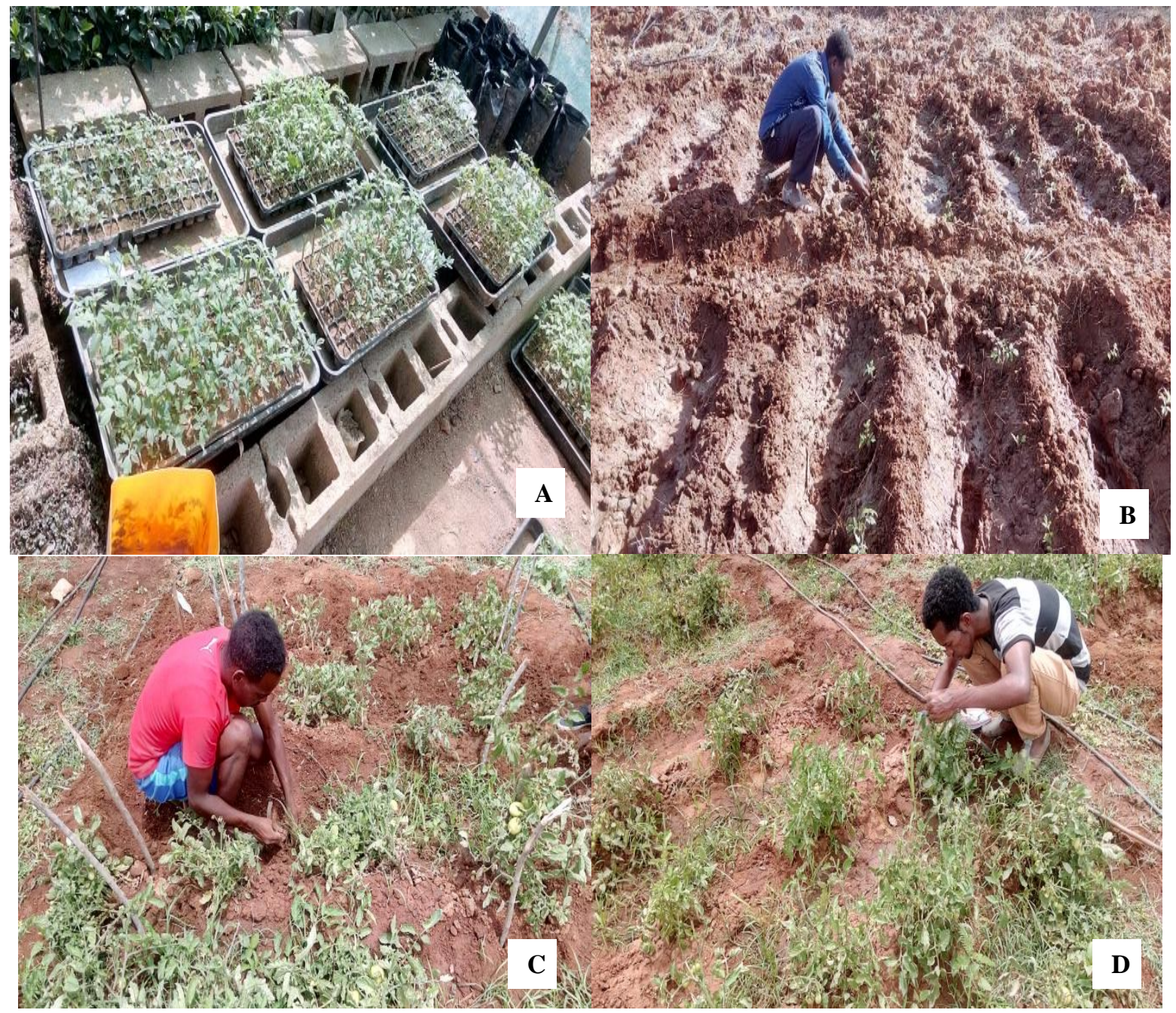

Fig.4 Flowers of Lantana camara (A) and seed kernels powder of Balanites aegyptiaca (B); Preparation of aqueous extract of flowers of Lantana camara and seed kernel aqueous extract of Balanites aegyptiaca (C) in Plant Protection Laboratory
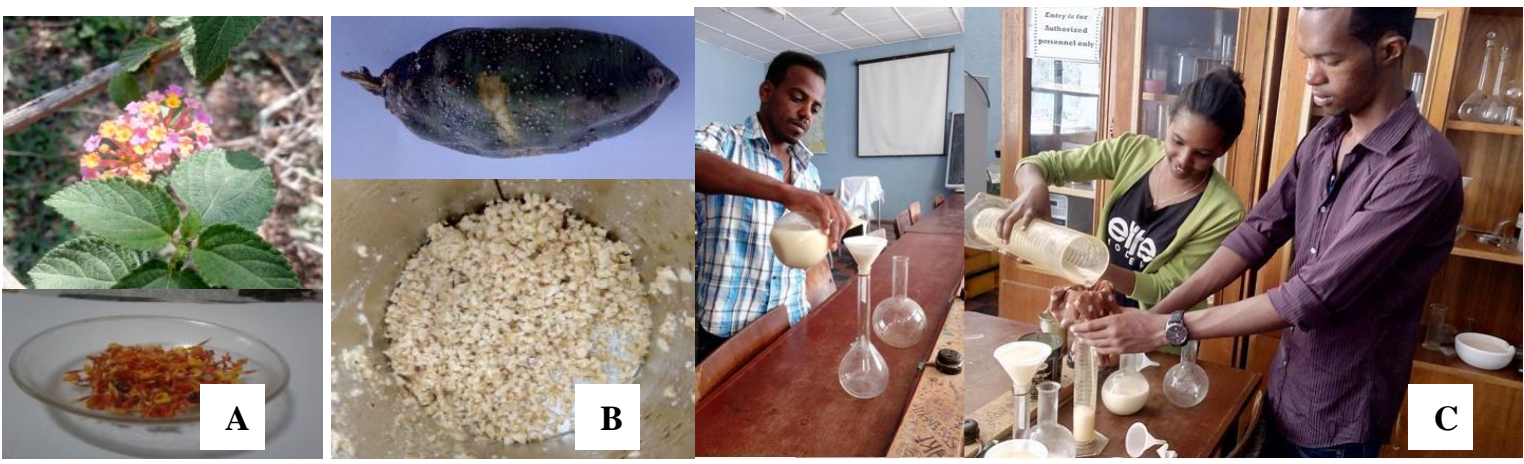
Fig.5 (A) Leafminer (Liromyza trifoli); (B) Fruit borer (Helicoverpa armigera) intermingled with Bacterial rot infections; (C) Bacterial Speck Disease; (D) Larva of fruit borer; (E) Whitefly

(Bemisia tabaci); (F) Tomato Leaf Curl Virus and (G) Early blight disease
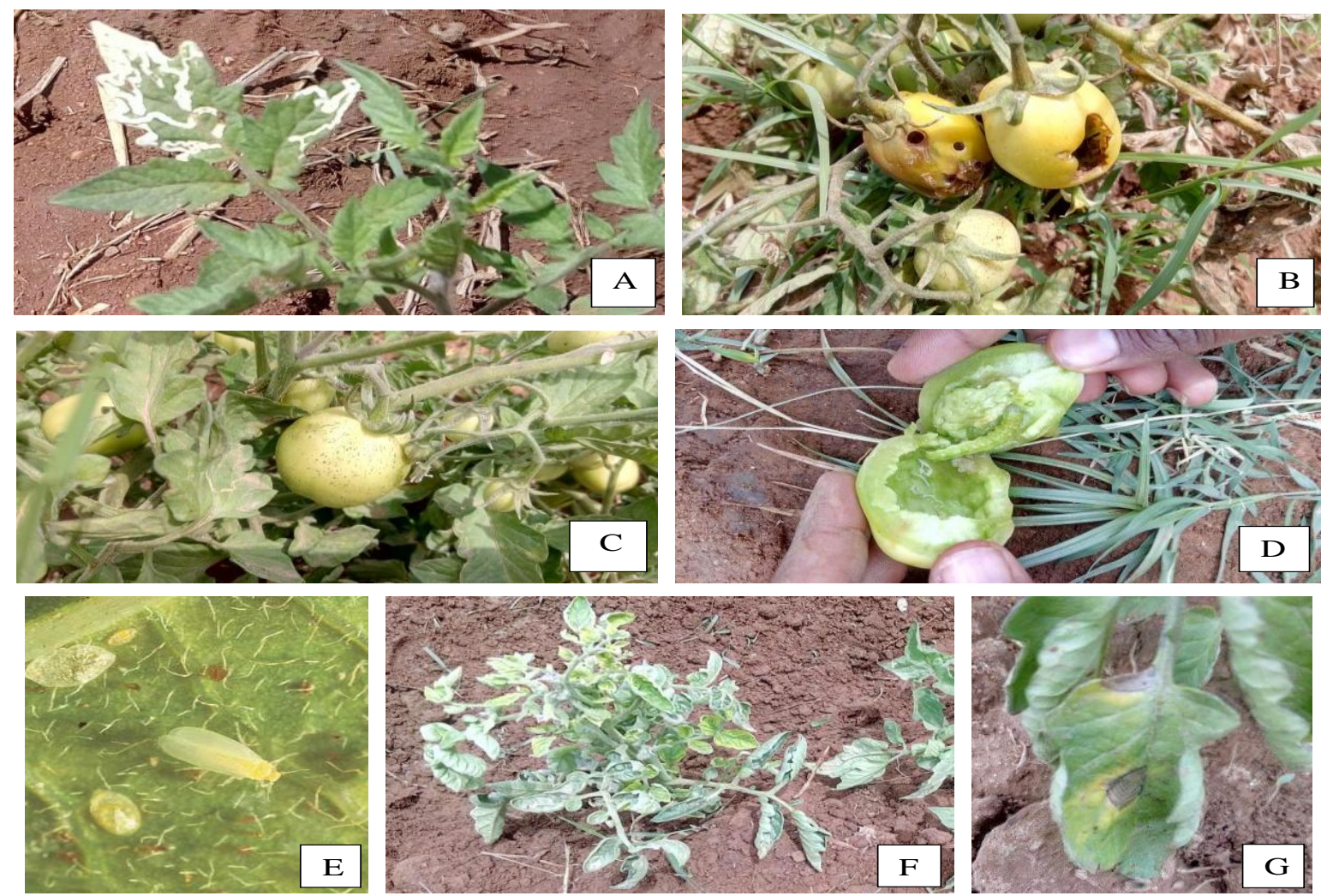

Design and Layout of the Experiment

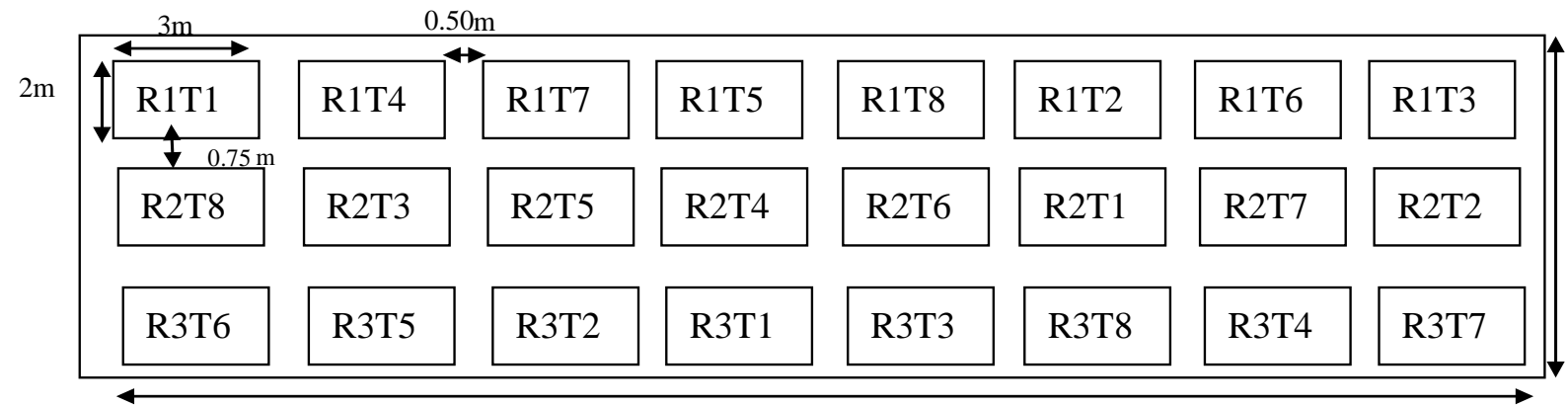

Where:

T1= Aqueous extract of Lantana flower 5\% (LFE)

$\mathrm{T} 2=$ Aqueous extract of Balanites seed kernel 5\% (BSKE)

$\mathrm{T} 3=$ Fungicide for Soil borne fungus $(\mathrm{SBF})$

T4= Fungicide Foliar Spray (FSF)

$\mathrm{T} 5=\mathrm{T} 1+\mathrm{T} 3 ;(50 \%+50 \%)$

$\mathrm{T} 6=\mathrm{T} 3+\mathrm{T} 4 ;(50 \%+50 \%)$

$\mathrm{T} 7=\mathrm{T} 2+\mathrm{T} 4 ;(50 \%+50 \%)$

$\mathrm{T} 8=$ Control

$\mathrm{R} 1=$ Row one; R2=Row two and R3= Row three. 
Table.1 Type of Chemicals used during the Research Work

\begin{tabular}{|l|l|l|l|}
\hline \multicolumn{2}{|c|}{ Mancozeb (Dithiocarbamate) } & \multicolumn{1}{c|}{ Punzix } & \multicolumn{1}{c|}{ Sulphur dust } \\
\hline \multicolumn{1}{|c|}{ Trade name } & \multicolumn{1}{c|}{ Anadoul } & \multicolumn{1}{c|}{ Punzix } & \multicolumn{1}{c|}{ HELB-sulphur } \\
\hline Dose per hectare & 250g/100 lt of $\mathrm{H}_{2} \mathrm{O}$. & $50-100 \mathrm{ml} / 200 \mathrm{lt} \mathrm{H}_{2} \mathrm{O}$ & $25-35 \mathrm{~kg} / \mathrm{ha}$ \\
\hline Active ingredient & $800 \mathrm{~W} . \mathrm{P}$. & Cypermethrine $10 \% \mathrm{WV}$ & sulphur \\
\hline Site of Application & Foliar application & Foliar application & Soil application \\
\hline Type of pesticide & Fungicide & Insecticide & Fungicide \\
\hline $\begin{array}{l}\text { Target } \\
\text { pests/diseases }\end{array}$ & $\begin{array}{l}\text { Early and Late Blight, } \\
\text { and Septoria Leaf Spot }\end{array}$ & Leaf miner & $\begin{array}{l}\text { Scab, powdery mildew, } \\
\text { rust, leaf worm }\end{array}$ \\
\hline
\end{tabular}

Source: (EDMS, 2004; Act 36/1947).

Table.2 Grade 'Rating Scale' of diseases on tomato

\begin{tabular}{|c|c|c|}
\hline Grade & $\%$ of disease & Nature of infection \\
\hline $\mathbf{0}$ & 0 & No conspicuous symptoms observed \\
\hline 1 & $0.1-0.9$ & $\begin{array}{l}\text { A few scattered plant diseased but 1-2 signs \&/or symptoms/plant } \\
\text { (Very Highly Resistant) }\end{array}$ \\
\hline 2 & $1.0-4.9$ & $\begin{array}{l}\text { A few scattered plant diseased but 5-10 signs \&/or symptoms/plant } \\
\text { (Highly Resistant) }\end{array}$ \\
\hline 3 & $5.0-9.9$ & $\begin{array}{l}\text { A few plant diseased but } 11-25 \text { signs \&/or symptoms /plant } \\
\text { (Resistant) }\end{array}$ \\
\hline 4 & $10.0-24.9$ & $\begin{array}{l}\text { A few plant diseased but } 26-50 \text { signs and/or symptoms /plant } \\
\text { (Moderately Resistant) }\end{array}$ \\
\hline 5 & $25.0-49.9$ & $\begin{array}{l}\text { Disease more common nearly every leaf let infected but plant remains } \\
\text { normal in form, field looks normal green. (Moderately Susceptible) }\end{array}$ \\
\hline 6 & $50.0-74.9$ & $\begin{array}{l}\text { Every plant diseased and about 5\% leaf area is destroyed, field } \\
\text { appears green dead. (Susceptible) }\end{array}$ \\
\hline 7 & $75.0-94.9$ & $\begin{array}{l}\text { About } 75 \% \text { leaf area destroyed, field appears predominantly dried or } \\
\text { green. (Highly Susceptible) }\end{array}$ \\
\hline 8 & 95.0-99.9 & Only few leaves on plants but stem green. (Very Highly Susceptible) \\
\hline 9 & $>99.9$ & All leaves dead, stem drying. (Very Highly Susceptible) \\
\hline
\end{tabular}

Table.3 Common Insect Pests and Diseases Identified on Tomato Crop

\begin{tabular}{|c|c|c|c|}
\hline Common name & Scientific name & Order & Family \\
\hline Leafminer $^{(i)}$ & Liromyzatrifoli & Diptera & Agromyzidae \\
\hline Whitefly ${ }^{(i)}$ & Bemisiatabaci & Hemiptera & Aleurodidae \\
\hline Fruit borer ${ }^{(i)}$ & Helicoverpaarmigera & Lepidoptera & Noctuidae \\
\hline Bacterial rot $^{(\mathbf{b})}$ & Ralstonia solanacearum & Eubacteriales & Eubacteriacea \\
\hline Bacterial speck $^{(b)}$ & Pseudomonassyringae & - & Pseudomonadaceae \\
\hline Tomato Leaf Curl Virus ${ }^{(v)}$ & TLCV & - & Geminiviridae \\
\hline Early blight $^{(f)}$ & Alternaria solani & Moniales & Dematiaceae \\
\hline
\end{tabular}

${ }^{(b)}$ : bacterial disease ${ }^{(\mathrm{f})}$ : fungal disease ${ }^{(\mathrm{i})}$ : insect pest ${ }^{(\mathrm{v})}$ : viral disease 
Table.4 Effect of Various Treatments on Percentage of Disease Incidence on Tomato in HAC

\begin{tabular}{|c|c|c|c|c|c|c|c|c|c|}
\hline & & & & \multicolumn{4}{|c|}{$\%$ of Disease Incidence } & & \\
\hline & Pathogens identified & \multicolumn{2}{|c|}{ Alternaria solani } & \multicolumn{2}{|c|}{$\begin{array}{c}\text { Ralstonia } \\
\text { solanacearum }\end{array}$} & \multicolumn{2}{|c|}{$\begin{array}{c}\text { Pseudomonas } \\
\text { syringae }\end{array}$} & \multicolumn{2}{|c|}{$\begin{array}{l}\text { Tomato Leaf Curl } \\
\text { Virus }\end{array}$} \\
\hline & Treatments & $\begin{array}{c}\text { Before } \\
\text { Treatment }\end{array}$ & $\begin{array}{c}\text { After } \\
\text { Treatment }\end{array}$ & $\begin{array}{c}\text { Before } \\
\text { Treatment }\end{array}$ & $\begin{array}{c}\text { After } \\
\text { Treatment }\end{array}$ & $\begin{array}{c}\text { Before } \\
\text { Treatment }\end{array}$ & $\begin{array}{c}\text { After } \\
\text { Treatment }\end{array}$ & $\begin{array}{c}\text { Before } \\
\text { Treatment }\end{array}$ & $\begin{array}{c}\text { After } \\
\text { Treatment }\end{array}$ \\
\hline T1 & Aqueous extract of Lantana flower 5\% & 71.52 & 68.27 & 15.12 & 13.9 & 56.7 & 55.6 & 71.11 & 67.84 \\
\hline $\mathbf{T} 2$ & Aqueous extract of Balanites seed kernel 5\% & 81.29 & 80.71 & 10.53 & 9.73 & 43.9 & 44.5 & 72.22 & 68.67 \\
\hline T3 & Sulphur dust & 79.41 & 78.9 & 17.72 & 16.67 & 35.6 & 33.3 & 55.56 & 53.46 \\
\hline T4 & Mancozeb & 80.04 & 79.85 & 22.75 & 22.23 & 68.75 & 66.7 & 51.11 & 51 \\
\hline T5 & $\begin{array}{l}\text { Aqueous extract of Lantana flower and } \\
\text { sulphur dust }\end{array}$ & 72.51 & 72.51 & 12.27 & 10 & 44.87 & 44.5 & 54.45 & 52.22 \\
\hline T6 & Sulphur dust and Mancozeb & 68.52 & 66.52 & 7.61 & 5.56 & 33.5 & 33.3 & 66.67 & 65.55 \\
\hline T7 & $\begin{array}{l}\text { Aqueous extract of Balanites seed kernel and } \\
\text { Mancozeb }\end{array}$ & 70.5 & 70.17 & 8.93 & 8.3 & 56.38 & 55.6 & 66.67 & 65.25 \\
\hline \multirow[t]{3}{*}{ T8 } & Control & 85.51 & 85.58 & 29.37 & 30.83 & 43.31 & 44.5 & 68 & 71.33 \\
\hline & L.S.D & \multicolumn{2}{|c|}{6.96} & \multicolumn{2}{|c|}{15.33} & \multicolumn{2}{|c|}{6.45} & \multicolumn{2}{|c|}{5.58} \\
\hline & C.V & \multicolumn{2}{|c|}{16.2} & \multicolumn{2}{|c|}{30.6} & \multicolumn{2}{|c|}{11.4} & \multicolumn{2}{|c|}{7.5} \\
\hline
\end{tabular}


Table.5 Effect of Various Treatments on Percentage of Disease Severity on Tomato in HAC

\begin{tabular}{|c|c|c|c|c|c|c|c|c|c|}
\hline & & & & \multicolumn{4}{|c|}{$\%$ of Disease Severity } & & \\
\hline & \multirow{2}{*}{$\begin{array}{l}\text { Pathogens identified } \\
\text { Treatments }\end{array}$} & \multicolumn{2}{|c|}{ Alternaria solani } & \multicolumn{2}{|c|}{$\begin{array}{l}\text { Ralstonia } \\
\text { solanacearum }\end{array}$} & \multicolumn{2}{|c|}{$\begin{array}{l}\text { Pseudomonas } \\
\text { syringae }\end{array}$} & \multicolumn{2}{|c|}{$\begin{array}{l}\text { Tomato Leaf Curl } \\
\text { Virus }\end{array}$} \\
\hline & & $\begin{array}{l}\text { Before } \\
\text { Treatment }\end{array}$ & $\begin{array}{c}\text { After } \\
\text { Treatment }\end{array}$ & $\begin{array}{l}\text { Before } \\
\text { Treatment }\end{array}$ & $\begin{array}{c}\text { After } \\
\text { Treatment }\end{array}$ & $\begin{array}{l}\text { Before } \\
\text { Treatment }\end{array}$ & $\begin{array}{c}\text { After } \\
\text { Treatment }\end{array}$ & $\begin{array}{l}\text { Before } \\
\text { Treatment }\end{array}$ & $\begin{array}{c}\text { After } \\
\text { Treatment }\end{array}$ \\
\hline T1 & Aqueous extract of Lantana flower 5\% & 24.67 & 21.5 & 8.38 & 6.56 & 14.27 & 12.2 & 12.94 & 12.44 \\
\hline $\mathbf{T 2}$ & $\begin{array}{l}\text { Aqueous extract of Balanitesseed kernel } \\
5 \%\end{array}$ & 16.33 & 11.3 & 7.56 & 6.78 & 21.55 & 22.3 & 14.83 & 12.22 \\
\hline T3 & Sulphur dust & 13 & 10 & 5.5 & 4.55 & 15.22 & 14.11 & 13.52 & 12.94 \\
\hline T4 & Mancozeb & 23.75 & 20.7 & 3.33 & 2.78 & 3 & 1.89 & 18.77 & 17.95 \\
\hline T5 & $\begin{array}{l}\text { Aqueous extract of Lantana flower and } \\
\text { sulphur dust }\end{array}$ & 14.55 & 23.75 & 6.76 & 4.33 & 13.77 & 13.55 & 16.44 & 15.5 \\
\hline T6 & Sulphur dust and Mancozeb & 17.33 & 15.5 & 4.27 & 1.78 & 1.39 & 1.44 & 19.22 & 18.11 \\
\hline T7 & $\begin{array}{l}\text { Aqueous extract of Balanites seed kernel } \\
\text { and Mancozeb }\end{array}$ & 24.44 & 23.45 & 4.33 & 3.88 & 12 & 11.12 & 14.16 & 13.55 \\
\hline \multirow[t]{3}{*}{ T8 } & Control & 7.78 & 11.3 & 3.55 & 5 & 1.11 & 2 & 23.12 & 26.61 \\
\hline & L.S.D & \multicolumn{2}{|c|}{3.99} & \multicolumn{2}{|c|}{1.49} & \multicolumn{2}{|c|}{1.59} & \multicolumn{2}{|c|}{3.13} \\
\hline & C.V & \multicolumn{2}{|c|}{19.4} & \multicolumn{2}{|c|}{25.6} & \multicolumn{2}{|c|}{13.6} & \multicolumn{2}{|c|}{16.6} \\
\hline
\end{tabular}


Table.6 Effect of Various Treatments on Percentage of Pest Incidence on Tomato in HAC

\begin{tabular}{|c|c|c|c|c|c|c|c|}
\hline & & \multicolumn{6}{|c|}{ \% Incidence of Pest infestation } \\
\hline & Insect pests observed & \multicolumn{2}{|c|}{$\begin{array}{c}\text { African Boll Worm } \\
\text { larval } \\
\text { population/plant }\end{array}$} & \multicolumn{2}{|c|}{$\begin{array}{c}\text { White Fly } \\
\text { population/plant }\end{array}$} & \multicolumn{2}{|c|}{$\begin{array}{l}\text { Leaf Miner \% } \\
\text { infestation }\end{array}$} \\
\hline & Treatments & $\begin{array}{l}\text { Before } \\
\text { Treatment }\end{array}$ & $\begin{array}{l}\text { After } \\
\text { Treatment }\end{array}$ & $\begin{array}{l}\text { Before } \\
\text { Treatment }\end{array}$ & $\begin{array}{l}\text { After } \\
\text { Treatment }\end{array}$ & $\begin{array}{l}\text { Before } \\
\text { Treatment }\end{array}$ & $\begin{array}{l}\text { After } \\
\text { Treatment }\end{array}$ \\
\hline $\mathbf{T 1}$ & Aqueous extract of Lantana flower 5\% & 7.69 & 1.67 & 10.64 & 6.52 & 18.4 & 11.2 \\
\hline $\mathbf{T 2}$ & Aqueous extract ofBalanitesseed kernel $5 \%$ & 21.15 & 13.34 & 14.89 & 4.34 & 18.4 & 7.5 \\
\hline T3 & Sulphur dust & 11.54 & 13.34 & 6.38 & 10.86 & 17.4 & 18.1 \\
\hline T4 & Mancozeb & 7.69 & 15 & 17.02 & 21.73 & 21.6 & 23.4 \\
\hline T5 & Aqueous extract of Lantana flower and sulphur dust & 25 & 11.67 & 21.27 & 15.21 & 17.2 & 14.7 \\
\hline T6 & Sulphur dust and Mancozeb & 11.53 & 8.33 & 19.14 & 13.04 & 19.3 & 11.3 \\
\hline $\mathbf{T 7}$ & Aqueous extract of Balanites seed kernel and Mancozeb & 9.61 & 25 & 6.38 & 10.86 & 20.1 & 22.3 \\
\hline \multirow[t]{3}{*}{ T8 } & Control & 5.76 & 11.67 & 4.25 & 17.39 & 26.1 & 28.4 \\
\hline & L.S.D & \multicolumn{2}{|c|}{4.143} & \multicolumn{2}{|c|}{3.403} & \multicolumn{2}{|c|}{3.81} \\
\hline & C.V & \multicolumn{2}{|c|}{29} & \multicolumn{2}{|c|}{22.5} & \multicolumn{2}{|c|}{17.7} \\
\hline
\end{tabular}


Table.7 Fruit Yield and Percentage Loss in Different Treatments

\begin{tabular}{|l|l|c|c|c|}
\hline & Treatments & kg/ plot & $\begin{array}{c}\text { Average } \\
\text { percentage } \\
\text { loss }\end{array}$ & $\begin{array}{c}\text { Net } \\
\text { product }\end{array}$ \\
\hline T1 & Aqueous extract of Lantana flower 5\% & 3.27 & 11.795 & 2.884 \\
\hline T2 & Aqueous extract of Balanites seed kernel 5\% & 3.74 & 10.575 & 3.345 \\
\hline T3 & Sulphur dust & 2.114 & 6.51 & 1.97 \\
\hline T4 & Mancozeb & 1.86 & 20.725 & 1.475 \\
\hline T5 & $\begin{array}{l}\text { Aqueous extract of Lantana flower and } \\
\text { sulphur dust }\end{array}$ & 3.92 & 1.525 & 3.86 \\
\hline T6 & Sulphur dust and Mancozeb & 2.23 & 12.61 & 1.949 \\
\hline T7 & $\begin{array}{l}\text { Aqueous extract of Balanites seed kernel and } \\
\text { Mancozeb }\end{array}$ & 2.47 & 12.88 & 2.152 \\
\hline T8 & Control & 1.2 & 4.92 & 1.14 \\
\hline & Total yield & 20.804 & 10.1025 & 18.71 \\
\hline
\end{tabular}

White fly population was found in T8 $4.25 \%$ before treatment and $17.39 \%$ after treatment for which the treatment is actually control but herein should be noticed to avoid confusion for percentages of before and after treatment are separately noted just for the purpose of record, whereas, by $\mathrm{T} 2$ the population of whiteflies were drastically controlled from $14.89 \%$ to $4.34 \%$. According to present obtained data, the extracts of Lantana and Balanites showed significant difference in comparison to all the treatments.

The percentage of incidence of Leaf miner population was observed with a maximum in both before treatment $(26.1 \%)$ and after treatment $(28.4 \%)$ in $\mathrm{T} 8$ and $\mathrm{T} 4$ with before and after treatments was $21.6 \%$ and $23.4 \%$ respectively. A drastic control of Leafminer was noticed by $\mathrm{T} 2$ and $\mathrm{T} 6$ from $18.4 \%$ to $7.5 \%$ and from $19.3 \%$ to $11.3 \%$ before and after treatments respectively. T2 showed highest significant difference in the control of whitefly. Generally, the highest incidence was observed in leaf miner by T8 (28.4\%), and the lowest is seen in whitefly byT8 $(4.25 \%)$. The treatments above against the mentioned pests showed a significant difference among when compared to control and the C.V calculated in
ABW and whitefly is 29 and 22.5 respectively. T5 ('aqueous extract of Lantana flower 5\% plus sulphur dust') showed the highest significance approximated to $13.33 \%$ decrease in population of $\mathrm{ABW}$ compared to all the other treatments and to all other pests. The present investigation supporting the result of Miller et al., 2005 and Gullino et al., 2010, that the Mancozeb is often used in combination with other active ingredients as it has many sites of action, therefore delaying the occurrence of pathogen resistant strains. The present investigation reveals insecticidal potentialities of Balanites aegyptiaca due to the presence of highly active chemical constituents like alkaloid, saponin flavonoid and other organic acids, mainly embedded on the fruit mesocarp (Chavan et al., 2014).

Table 7 reflects the yield loss due to the infections and infestation by both pathogens and insect pests. It is estimated that the total yield was acquired $20.804 \mathrm{~kg} / \mathrm{plot}$ whereas, the percentage yield loss was evaluated $10.1025 \%$. In the treatments of $\mathrm{T} 5, \mathrm{~T} 2$ and $\mathrm{T} 1$, a more net product yield was obtained 3.86, 3.35 and 2.89 respectively. Application of 'Aqueous extract of 'Lantana flower and sulphur dust' on the tomato crop showed the 
least percentage yield loss $(1.525 \%)$, on the other hand, $20.73 \%$ which is the highest yield loss was recorded in the application of treatment of 'Mancozeb'. The T4 (Mancozeb) showed no control over the insect pests, after treatment and hence it could not improve the yield, due to the yield which was also recorded less $(1.86 \mathrm{~kg} / \mathrm{plot})$ in the treated crop, following the least yield loss observed in control. Then, the similar trend follows in treatment of 'sulphur dust' (T3) which showed a decrease in yield when compared to the other treatments although the highest yield loss was recorded in T4. The result exhibited that mancozeb showed negligible significance in managing the diseases and did no significant control on the insect pests compared to the other treatments. Therefore thehighest yield loss was recorded in it.

\section{Recommendation}

Though it is difficult to recommend on the base of a few months study, but the present investigation reveals to the farmers that treatments of the aqueous extract of Lantana flower 5\%, 'Aqueous extract of Balanites kernel 5\%', 'Sulphur dust plus Mancozeb' and Aqueous extract of 'Lantana flower 5\% plus sulphur dust' were the best applications for the controlling the diseases as well as insect pest.

\section{Future Line of Work}

Further research study on the application of botanicals and their combinations and at the different climatic conditions is needed for the managing the various diseases on tomato and other crops. The application of chemicals is not a solution for eradication of the diseases, on top of it, they may cause some another side effects on the human kind. To maintain the ecological balance and to avoid the magnification of chemicals it is encouraged to make use of plant extracts.

\section{Acknowledgments}

The authors are grateful to the Department of Plant Protection staff, Hamelmalo Agricultural College (HAC) for their technical support. The authors also extend great thanks to the farm manager, HAC. In addition to this, our gratitude goes to $\mathrm{Mr}$. Danial Brhaneand Mr. Royrick for their comments on this manuscript.

\section{References}

Agrios, G.N. 2005. Plant pathology, $5^{\text {th }}$ Ed, Department of plant pathology university of Florida, Elsevier Academic press 30 corporate Drive, suite 400, Burlington, MA 01803, USA.

Andy Cherry, Matthew Cock, Henk van den Berg and Rami Kfir. 2003. Biological Control of HelicoverpaArmigera in Africa. $\mathrm{CAB}$ International-2003. Biological control in IPM systems in Africa. The ACP-EU Technical Centre for Agricultural and rural Co-operation (CTA). Postbus 380.The Netherlands. ISBN: 0-85199-639-6. www.cabi-publishing.org

Asgedom, S., D. Esselink, P.C. Struik and B. Vosman.2011. Diversity among and heterogeneity within tomato cultivars from Eritrea. Afr. J. Biotechnol., p. 10 (in press).

Basheer, A.H.2006. Tomatoes Perspective in Syria, NAPC, Syria. Bose TK, Kabis J, Maity TK (2002). Vegetable Crops 1, Bhukeni, Calcutta.

Bishnu Chapagain and Zeev Wiesman. 2005.Larvicidal effects of aqueous extracts of Balanites aegyptiaca (desert date) against the larvae of Culexpipiens mosquitoes. African Journal of Biotechnology Vol. 4 (11), pp. 1351-1354, ISSN 1684-5315. http://www.academicjournals.org/AJB.

Byers, J.A. 2015.General Biology and Ecology of Leaf miners. Entomology Research Programs. California, USA.

Chapagain, B.P., Z. Wiesmanand L. Tsror.2007. In vitro study of the antifungal activity of saponin-rich extracts against prevalent 
phytopathogenic fungi.Ind. Crops Prod. 26: 109-115.

Chavan, R.W., S.S. Khadabadi, S.S. Saboo and G.G. Tapadiya. 2014. An important Enthomedicinal Plant Balanites aegyptiaca Del. American Journal of Enthomedicine, Vol. 1, No. 3, 122-128.

EDMS. 1948. South Africa Act. 36 of 1947.Fertilizers, Farm Feeds, Agricultural Remedies and Stock Remedies Act 36 of 1947.

Eweis M., S. Amber, S. 2011. International journal of botany. 7(4). Control of Beta vulgaris using Lantana camera.Linn.Essential oil in vitro. Egypt.

Flint, M.L. 2006. Pests in Gardens and Landscapes.University of California.Statewide IPM programs.

Hanan A Al Ashaal, Ayman A Farghaly, M MAbd El Aziz and Mohamed A A Ali. 2009. Phytochemical investigation and medicinal evaluation of fixed oil of Balanites aegyptiaca fruits (Balantiaceae). Journal of Ethnopharmacology, 127(2):495501. DOI: 10.1016/j.jep. 2009.10.007. Source: PubMed.

International Centre of Insect Physiology and Ecology (ICIPE), 2016.Annual Report 2016. Nairobi, Kenya. icipe@icipe.org. www.icipe.org.

Maria LodovicaGullino, Federico Tinivella, Angelo Garibaldi and Gregory M Kemmitt. 2010. Mancozeb: Past, Present, and Future. Plant Disease 94(9): 1076-1087. DOI: 10.1094/PDIS-94-9-1076.

Miller, S. A. and Lewis Ivey, M. L. 2005.Hot water and chlorine treatment of vegetable seeds to eradicate bacterial pathogens. Ohio State University Extension Fact Sheet HYG-3085-05. http://www.oardc.ohiostate.edu/millerlab

Ministry of Agriculture. 2000. Horticulture Division Report, Asmara, Eritrea.

Reifschneider, F.J.B., P. Furumoto and F.A.R. Rilgueira. 1984. Illustrated key for the evaluation of early blight of potato. FAO.PI. Prot. Bull. 32(3): 91-94.

Rishikesh, M. 2013. Study on seasonal incidence of insect pest copmlex of tomato and their management with phyto extracts. A Thesis for Degree of Master Science.College of agriculture, India.

SethumadhavaRao, Syed Danish, Sham Keflemariam, HabenTesfagergish, RahwaTesfamariam, Tomas Habtemariam. 2016. Pathological Survey on Disease Incidence and Severity of Major Diseases on Tomato and Chilli Crops Grown in Sub Zoba Hamelmalo, Eritrea International Journal of Research Studies in Agricultural Sciences 2-1, 13-24.

Sithanantham, S. 2004. Development and Dissemination of IPM for Vegetables in Eastern Africa. International Centre of Insect Physiology and Ecology (ICIPE).ICIPE Science Press. Nairobi, Kenya. ISBN: 9290641665. http:/ /www.icipe.org

Weinzierl, R. A. 1998. Botanical insecticides, soaps, and oils.In J. E. Rechcigl and N. A. Rechcigl (eds.), Biological and biotechnological control of insectpests. Agriculture and Environment Series. CRC Press LLC. 101-122.

\section{How to cite this article:}

Niat Yemane, Russom Kiflu, G. Yonatan Teklemariam, G. Sethumadhava Rao and Syed Danish Y. 2019. Efficacy of Selected Aqueous Plant Extracts, Fungicides and Their Combinations against Disease and Pest Control on Tomato in Hamelmalo. Int.J.Curr.Microbiol.App.Sci. 8(08): 2906-2921. doi: https://doi.org/10.20546/ijcmas.2019.808.335 